\title{
Benefits of Social Business in Modern Society
}

\author{
Odeta GLUOKSNYTÉ1 1 , Živilè MYRU² \\ ${ }^{1}$ Marijampole University of Applied Sciences, Marijampole, Lithuania \\ ORCID ID 0000-0003-4504-9759 \\ 2 Marijampole University of Applied Sciences, Marijampole, Lithuania \\ ORCID ID 0000-0003-1802-0619 \\ Email: odetagl@yahoo.com, zivile.myru@mkolegija.lt
}

\begin{abstract}
Modern society still interprets social business as a socially responsible company that receives public incentive to employ people with disabilities. However, this article is intended to emphasize that social business has a greater advantage over traditional business organizations as it is an opportunity to solve social problems that are relevant to society in an entrepreneurial way and to demonstrate the benefits to a society. Training of social business specialists is not yet being widely implemented in Southern Lithuania, hence benefits of it are being discussed in the article for further possible actions to take. The article deals with the research problem and aim such as analysing the benefits of social business and to assess the consumers' perception of it.
\end{abstract}

Key words: economic activity, social business, transparent business, social exclusion.

\section{Introduction}

B. Melnik understands Social Business as a priority-oriented public interest which expresses various social aspirations that emerge and manifest in the life of modern society. The interest of modern society in social business is increased by state's incentive to employ people with disabilities and desire to reduce social exclusion. More new businesses are classified as social. The Law on Social Business Development of the Republic of Lithuania defines the conditions for the creation and development of social business, providing for the conditions for the establishment of social business and the state incentive (Melnik B, 2017).

Benefits of Social Business. The European Commission Communication on the Social Business Initiative states that the EU social economy is made up of entities with a specific status (cooperatives, foundations, associations, mutual societies), many of which are social businesses and those with traditional status of a sole or joint stock company (European Commission, Brussels, 2011).

The Social Business Concept of the Republic of Lithuania sets out the principles of managing organizations operating in the private sector that help achieve public sector goals, conduct commercial activities, and create social value for society. According to this business concept, social business is geared towards the public interest, which expresses the various aspirations of a social nature that are emphasized and manifest in the life of modern society (Social Business Concept of the Republic of Lithuania, 2015).

According to Jakubavicius, Leichter, Stumbryte, social business is a business with the main mission and purpose addressed directed social needs. Such a business may have additional goals, but they cannot prevail over social goals directed at society and its groups (Jakubavičius A., Leichter E. and Stumbrytė G., 2016).

For B. Melnik, social business is primarily geared towards social interest driven public aspirations and/or has only a subordinate entrepreneurial economic purpose or none (Melnik B., 2017).

How to recognize social business? While the traditional business model exploits the market for profit, social business tries to fill a niche that cannot be filled by public services. Social business activities can be identified by these distinctive characteristics of social business (Navasaitienè S., 2017):

- the primary purpose of social business must be focused on a social mission,

- it must carry on an economic activity and reinvest part of its profits in its core objectives,

- it must be financially and institutionally independent from the public sector,

- it must be transparent and accountable.

To assess benefits of social business, the researchers refer to the SOCIAL BUSINESS CONCEPT of the Republic of Lithuania, approved by the Minister of Economy of the Republic of Lithuania on 3 April 2015 by order No. 4-207. 3. stating that social business has three main dimensions: entrepreneurship (ongoing 
commercial activity), social (pursuit of social goals) and management (limited profit sharing, transparent management) (Social Business Concept of the Republic of Lithuania, 2015).

Therefore, social business encompasses principles and form of conducting business activities. How the process manifests itself in the application of business principles to social and environmental problems, how the activity is designed to solve social problems, by reinvesting profits without paying its stakeholders, and generates at least half of the proceeds from the sale of services or goods. In order to ensure delivery and accessibility of social services to all, social business must be flexible and able to attract different sources of material and intangible support to offer its goods and services to people on the lowest incomes, according to V. Kvietka (2015).

Another benefit of social business is social innovation, which is characterized by the dissemination of innovative social ideas that help to change social structures (Gembickienè V., Leonienė B, 2015).

Professor Muhammad Yunus distinguishes these principles of social business (Yunus, M., Moingeon, B. \& Lehmann-Ortega, L, 2010):

the mission of social business is to solve a particular social problem in society (through social innovation or the application of successful practices); social business is financially sustainable and has a viable business model; social business does not pay dividends to investors - its purpose is not to maximize shareholder capital; profit is used to solve a social problem or is reinvested in social business development; social business works in harmony with the environment; employees are paid market-level or higher salaries, and their working conditions are better than of an average company; social entrepreneurs believe in what they do, so they enjoy their job and realize themselves.

According to N. Stropute and M. Kairyte (2016), one of the indicators of social business is orientation to changes, which fundamentally transform the scale of the problem and find a new solution. Modern society's interest in social business is driven by the fact that it fills in a very important niche that neither business nor the state covers. Social business becomes more relevant because of (Stropute N., Kairytė M., 2019):

- reducing social exclusion and identifying changes in today's society,

- the tendency of continuously aging population, which is leading to changes in social security and health services sectors,

- ongoing systemic change in education and sustainable development,

- initiatives to become responsible consumers of welfare services,

- beginning to follow the do-it-yourself principle,

- increasing civic participation in different contexts.

The impact of social business on modern society is growing. To obtain funding from a municipality or other public institution, a business must demonstrate its activities and impact on society and demonstrate the work it has already done. This presentation of transparency of activities has a positive effect on public confidence in private initiative. It acts as a catalyst in important areas of a society - economic growth, education, and social infrastructure (Čižikienė J., Urmanavičienè A., 2016)

Impact of social business can be assessed by: motivating employees, solving environmental problems, assessing the quality of social services, ensuring participation of different social groups in society, ensuring measures to reduce social exclusion, integration of vulnerable members of society into the labour market and society, developing their social and working skills.

Relevance and importance of the study is the following: by focusing more on social mission and consumer needs, social business taking over some of the functions performed by the state in the field of social welfare: reducing social exclusion, addressing inequalities and environmental issues, promoting social cohesion.

Research problem: What are the benefits of social business in modern society in Southern part of Lithuania?

Research object: the benefits of social business in modern society.

Research aim is to assess consumer perceptions of the benefits of social business in modern society.

Research objectives:

1. Define the concept, activities and benefits of social business.

2. To assess the impact of social business in modern society.

3. Provide consumers research findings and recommendations. 


\section{Method}

\section{Subjects and sampling method}

In October-December 2019, the survey aimed to assess the respondents' knowledge of the concept of social business, its recognition characteristics, the identification of social business activities and the benefits they bring to modern society. This is an initial research as any surveys have been conducted before.

A questionnaire was drawn up during the survey. The first part of the questionnaire contains questions about consumer demographic data.

The second part aimed to evaluate the concept of social business, the differences between social business and social responsibility.

The third part aimed to analyse the benefits of social business.

V. Dikcius' formula was used to calculate the sample size:

$$
n=\frac{1}{(\Delta)^{2}+\frac{1}{N}}
$$

Here $\mathrm{n}$ - the size of the required sample with the possibility of sample error $\mathrm{P}=0,954$;

$\mathrm{N}$ - the total size;

$\Delta$ - the allowed sample error size $(\Delta=0,05)$

According to the data of Lithuania Department of Statistics, there were 138678 inhabitants in Marijampole county (35 241 in Marijampole city) (Lithuanian Department of Statistics):

$$
n=\frac{1}{(0,05)^{2}+\frac{1}{138678}}
$$

Calculation showed $n=398$ (subjects). The chosen method of quantitative research is survey. According to the sampling of the quantitative study, the subjects are of the simple random sampling type.

Due to time and financial resources, 150 questionnaires were sent out, 111 questionnaires were returned. Respondents were selected from Southern part of Lithuania. In the questionnaire, respondents were asked to choose one or more of provided options.

\section{Instruments of data recollection}

A questionnaire was developed during the study. Question types used: dichotomous, liqueur scale, and multivariate. The first part of the questionnaire asks questions about a user's demographics. The second part aimed to assess the concept of social business, differences between social business and social responsibility. The third part aimed to analyse the benefits of social business.

A valid study was conducted $(\mathrm{n}=111)$, the chosen quantitative research method (survey) achieved the goal (to evaluate consumers' opinion about the benefits of social business in a modern society).

\section{Plan and procedure}

Various scientific literature and Internet databases were analysed on the topic of social business. Respondents were therefore asked how they view the benefits of social business according to principles of social business by Nobel laureate Dr. Muhammad Yunus.

\section{Findings}

The aim of the research was to assess the respondents' knowledge of the concept of social business, its recognition characteristics, identification of social business activities and its benefits for modern society.

111 respondents participated in the survey: $77 \%$ women, $23 \%$ men, most of them were employees $(52 \%)$, civil servants (24\%), least of them were businesspeople (6\%), pupils (7\%), students (11\%).

Respondents' results on the concept of social business show that all statements are more or less in line with the concept of social business (see Figure 1). 


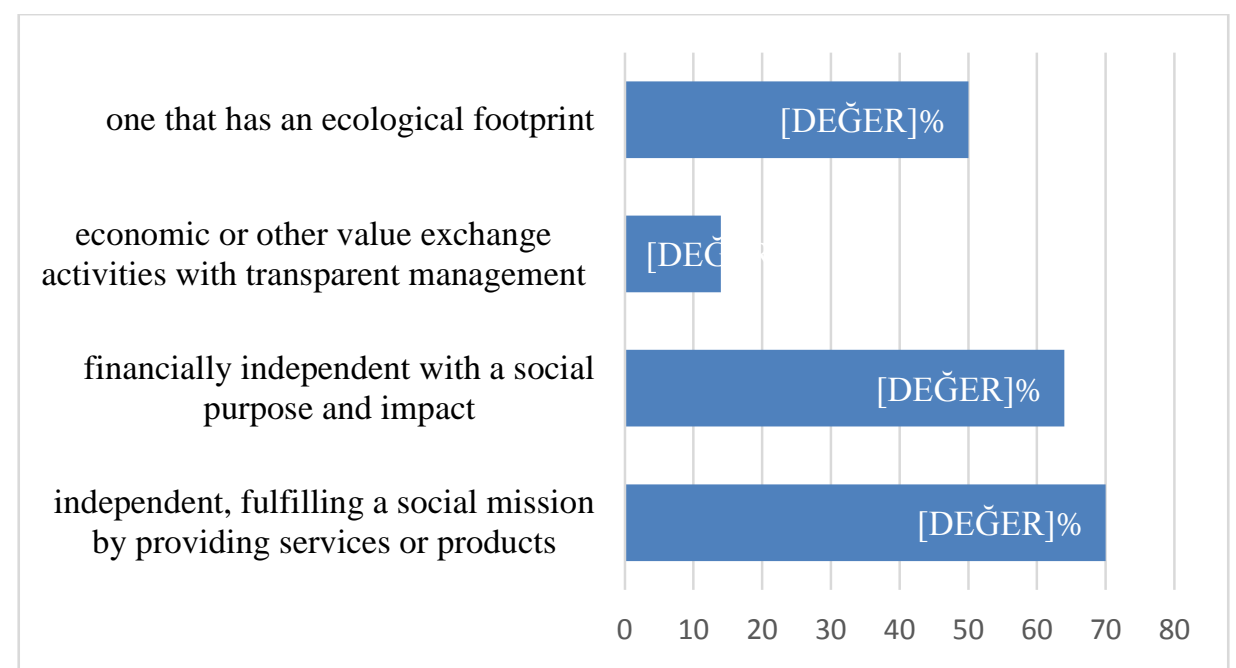

Figure 1. The concept of social business according to respondents

Respondents who participated in the survey recognize social business according to all the given characteristics. Most respondents identify social business with the primary goal of social mission (87\%). Half of the respondents said that transparency and accountability are an integral part of social business (see Figure 2).

transparent and accountable

financially and institutionally independent from the public sector

pursues economic activities and reinvests part of its profits in its core objectives

main purpose is directed towards a social mission

$$
\text { a }
$$$$
\begin{array}{llllll}
0 & 20 & 40 & 60 & 80 & 100
\end{array}
$$

\section{[DEĞER]\%}

\section{DEĞER]}

\section{$[\mathrm{DEĞER}] \%$}

\section{$[\mathrm{DEĞER}] \%$}

$60 \quad 80$

Figure 2. Characteristics of social business recognition according to respondents

The research aimed to assess benefits of social business. The greatest benefit of social business, according to the respondents, is when the profit goes to solve the social problem or is reinvested in the development of social business.

The attitude of modern society towards a product or service is shaped not only by the quality of the product or service, but also by the overall image and reputation of the company. Society is influenced by the development of social and working skills and the development of scientific and technological innovation. Therefore, after asking the respondents whether the mission of social business usually solves a particular social issue through social innovation, $71 \%$ of them agreed. (see Figure 3). 


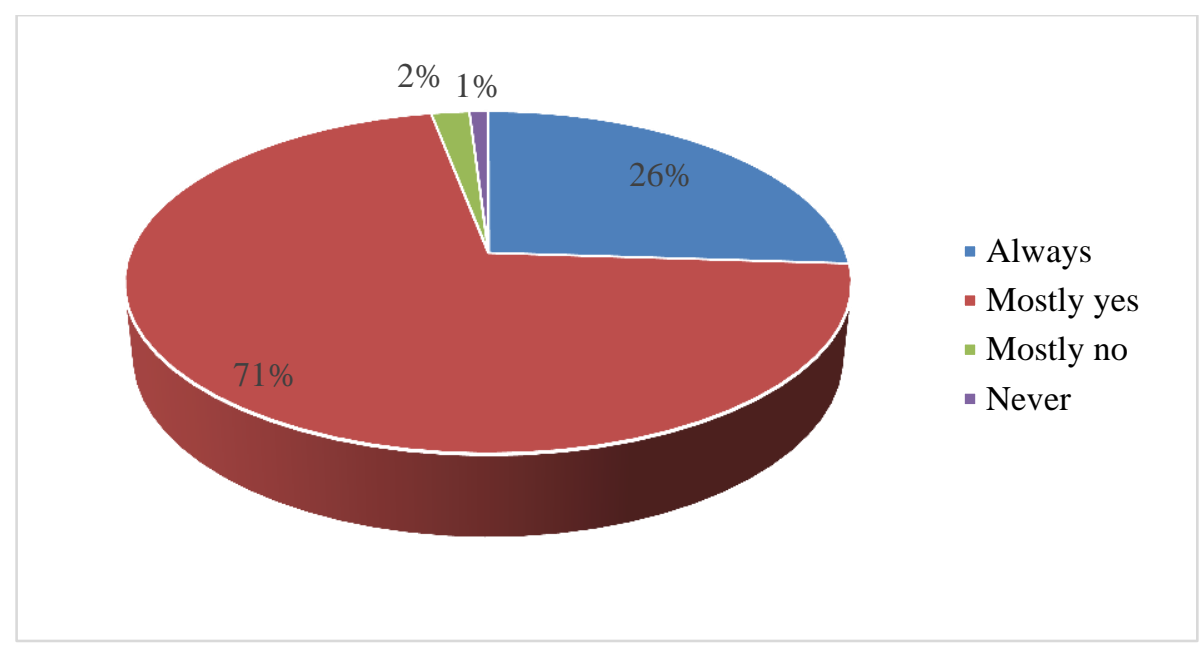

Figure 3. Distribution of respondents by benefit of social business (Business mission is to solve a particular social problem in society through social innovation)

Social business is good for social and economic development of society. In order to have a social business status, a company must meet the criteria set by the Ministry of Economy of the Republic of Lithuania: social, entrepreneurial, governance and independence. Therefore, most respondents agree that most (72\%) social business is financially sustainable and has a viable business model (see Figure 4).

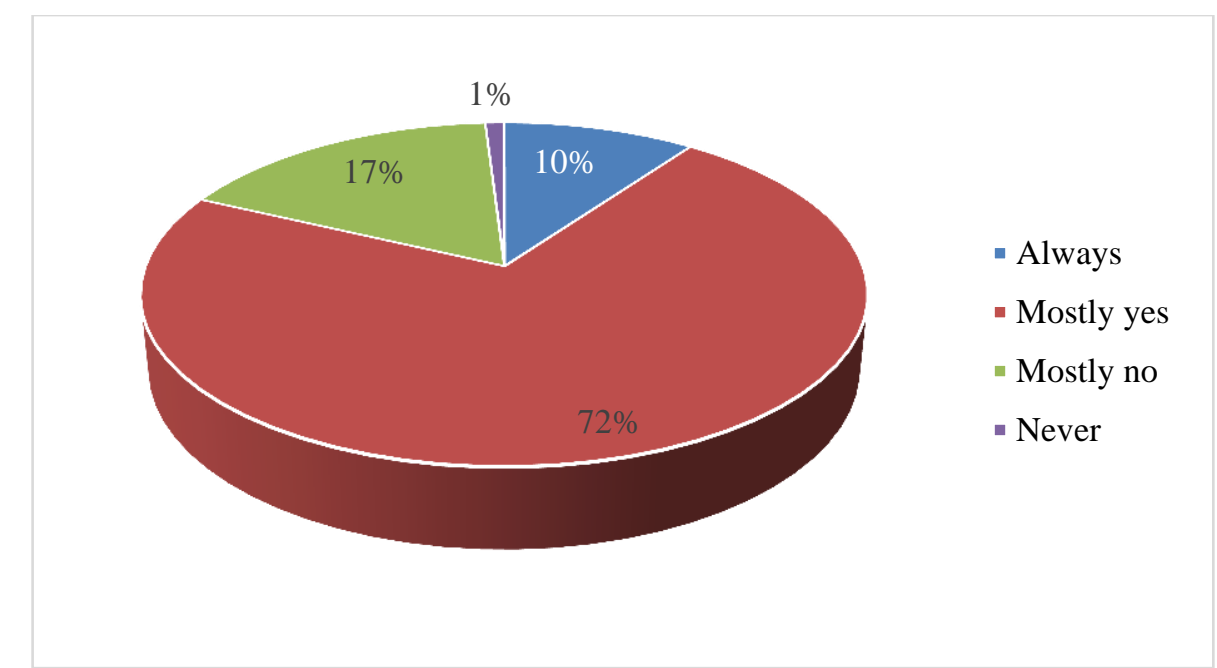

Figure 4. Distribution of respondents by benefit of social business (social business is financially sustainable, has a viable business model)

Social business carries out economic or other activities in the form of value exchange that pursue goals and social impacts that are beneficial to society or its group. The profits generated by these activities and a portion of them are dedicated for achieving the intended goal. This is a financially independent business that must generate at least $50 \%$ of its revenue from its operations. As a result, half of the respondents $(50 \%)$ think that social business does not pay dividends to investors as their purpose is not to maximize a shareholder capital (see Figure 5). 


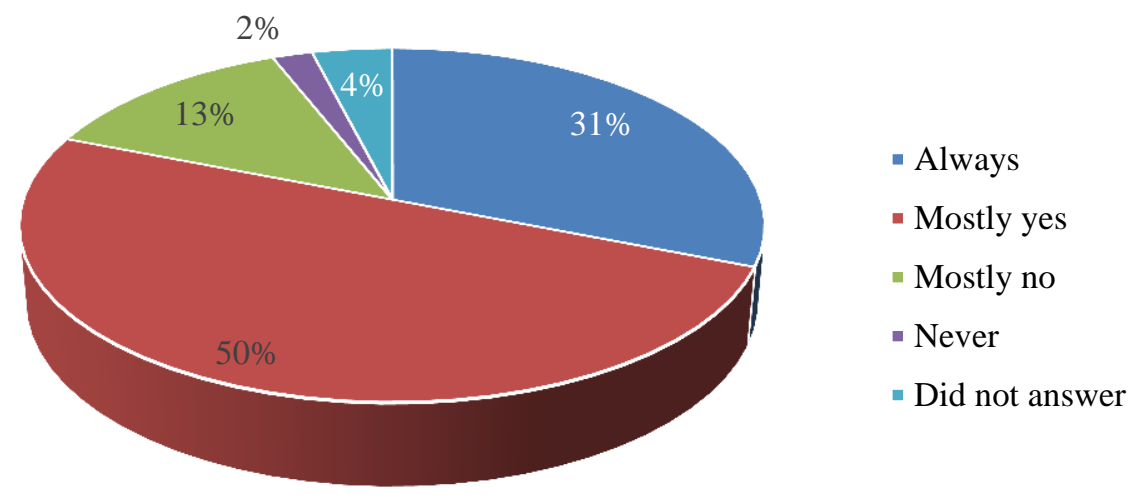

Figure 5. Distribution of respondents by benefit of social business (social business does not pay dividends to investors - its purpose is not to maximize shareholder capital)

In social business, profits are possible, but social goals are superior to the financial ones. As a result, respondents identified that the greatest benefit of social business (always 35\%, usually 55\%) is when it uses its profit to solve a social problem or reinvested in the development of social business (see Figure 6).

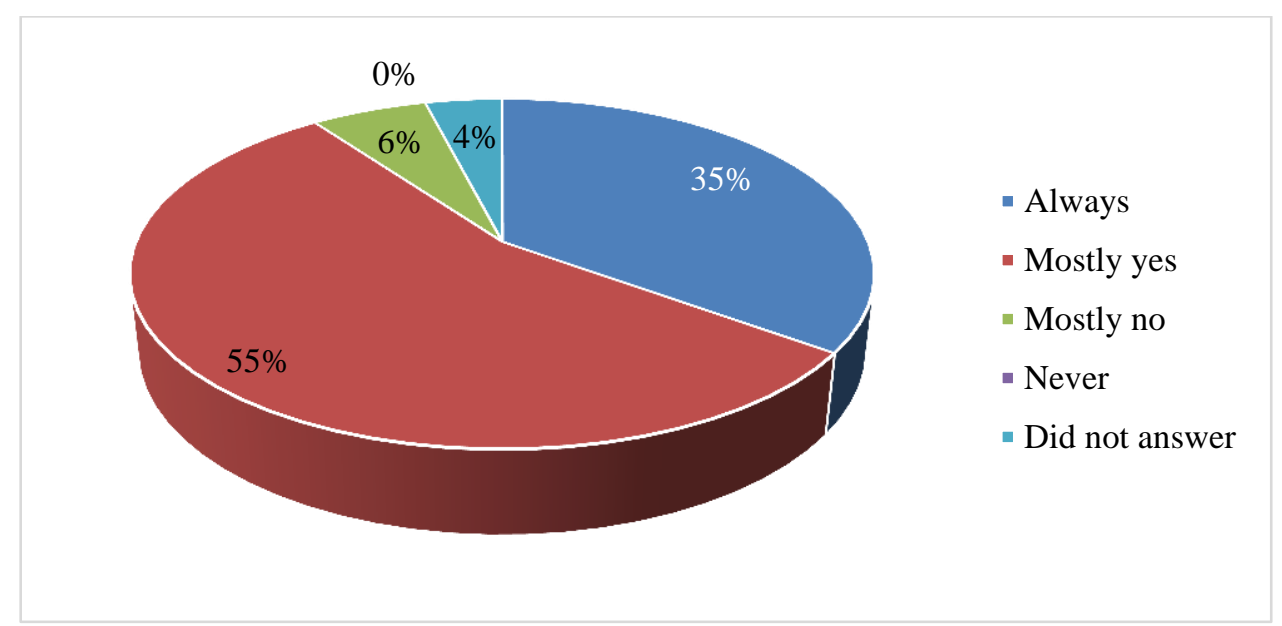

Figure 6. Distribution of respondents by benefit of social business (profit is used to solve a social problem or reinvested in the development of a social business)

Investing in the market of organic food and services can reduce business costs in the long run and increase efficiency of the company. The better the company meets the expectations and needs of society, the stronger it is in the society. Therefore, harmony with environment is very important (see Figure 7). 


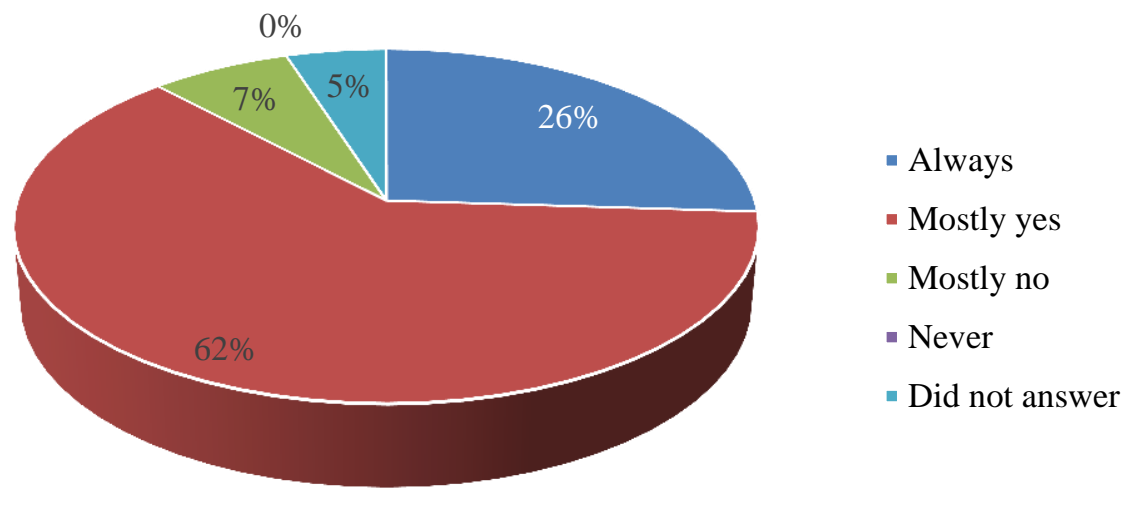

Figure 7. Distribution of respondents by benefit of social business (social business operates in harmony with the environment)

It could be stated, that as the structure of social business ownership reflects its mission and is usually focused on social justice as Corporate governance is accountable and transparent - involving employee than the majority of respondents tend to assume that the main motive for the employees is not the salary and so imagine that they do not receive market-level or higher salaries (see Figure 8).

Figure 8. Distribution of respondents by benefit of social business (employees receive salaries at market level or above)

The involvement of modern society in various social and civic contexts is becoming increasingly relevant. Majority of respondents (77\%) agreed that social business becomes more relevant due to reduction of social exclusion and identification of changes in today's society (see Figure 9). 


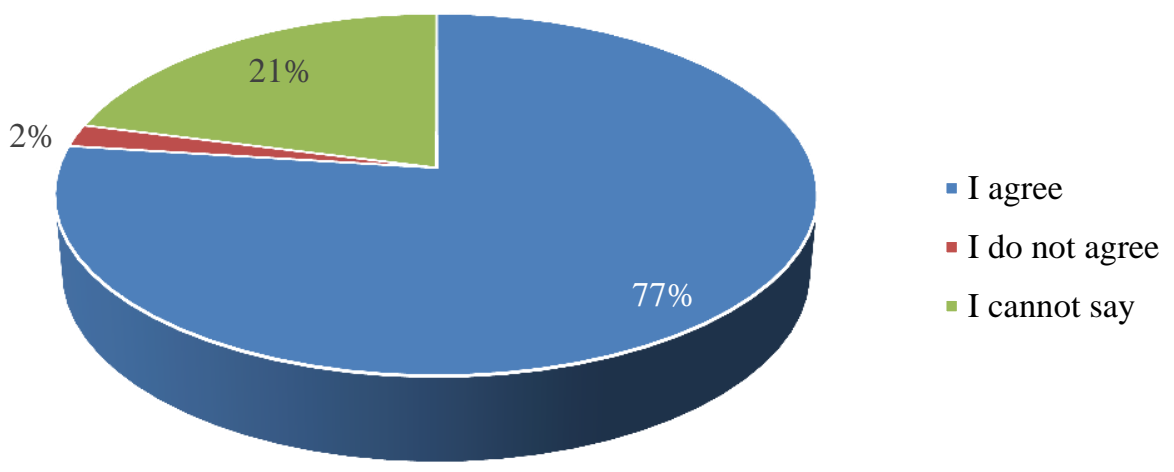

Figure 9. For respondents, social business becomes more relevant due to the reduction of social exclusion and the identification of changes in today's society

The tendency of increasing aging is leading to changes in social security and health care sectors. According to the respondents (66\%), participation of social business in the modern society becomes more relevant due to the aging society (see Figure 10).

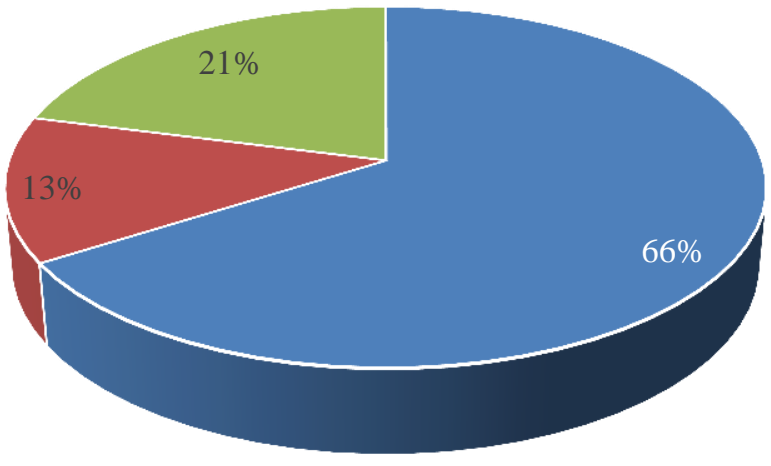

- I agree

- I do not agree

- I cannot say

Figure 10. Social business is becoming more relevant as a result of the aging population, leading to changes in social security and health care services

Education, training and personal development programmes are a long-term process which is usually integrated to the nature and purpose of social business activities. Various types of training, qualification improvement, social and working skills development (63\%) are an integral part of almost every organization (see Figure 11). 


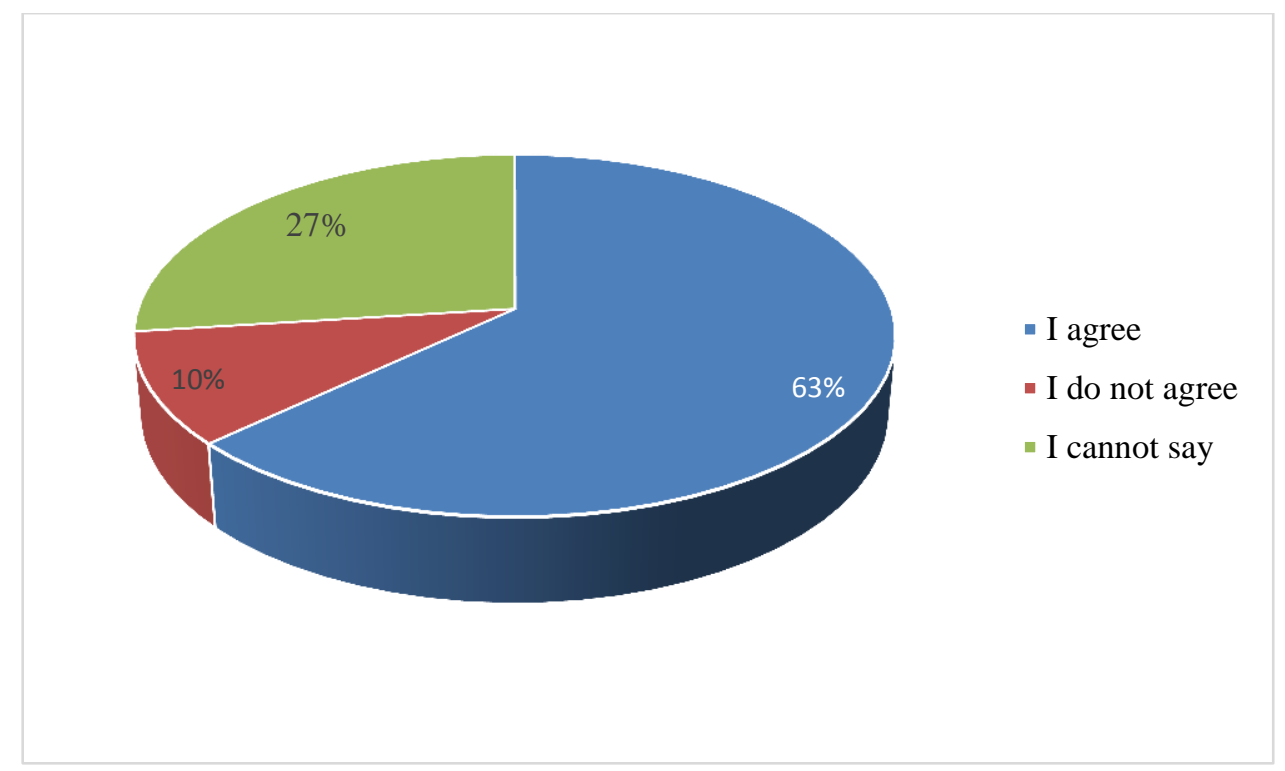

Figure 11. Social business is becoming more relevant to respondents today due to ongoing systemic change in education and sustainable development

Social business is good for social and economic development of society. Some of the functions performed by the state in the field of social welfare may be performed when social business is established. In order to find more effective solutions to social problems, people have to become responsible users of welfare services and start following the principle "do it yourself" (see Figure 12).

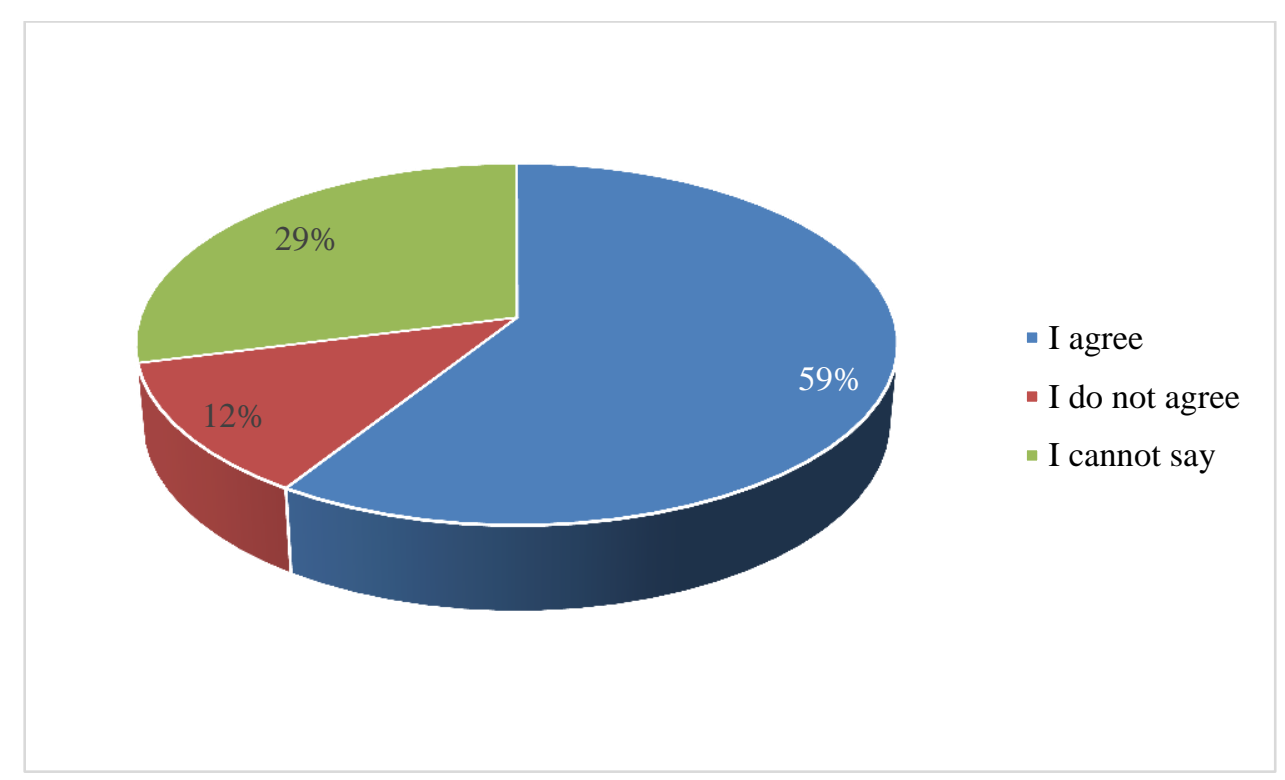

Figure 12. For respondents, social business becomes more relevant due to the initiative to become responsible consumers of welfare services and the principle "do it yourself"

Growing civic participation in different social contexts fosters social cohesion (e.g. in environmental pollution, reduction of consumerism, employment of disadvantaged people) (see Figure 13). 


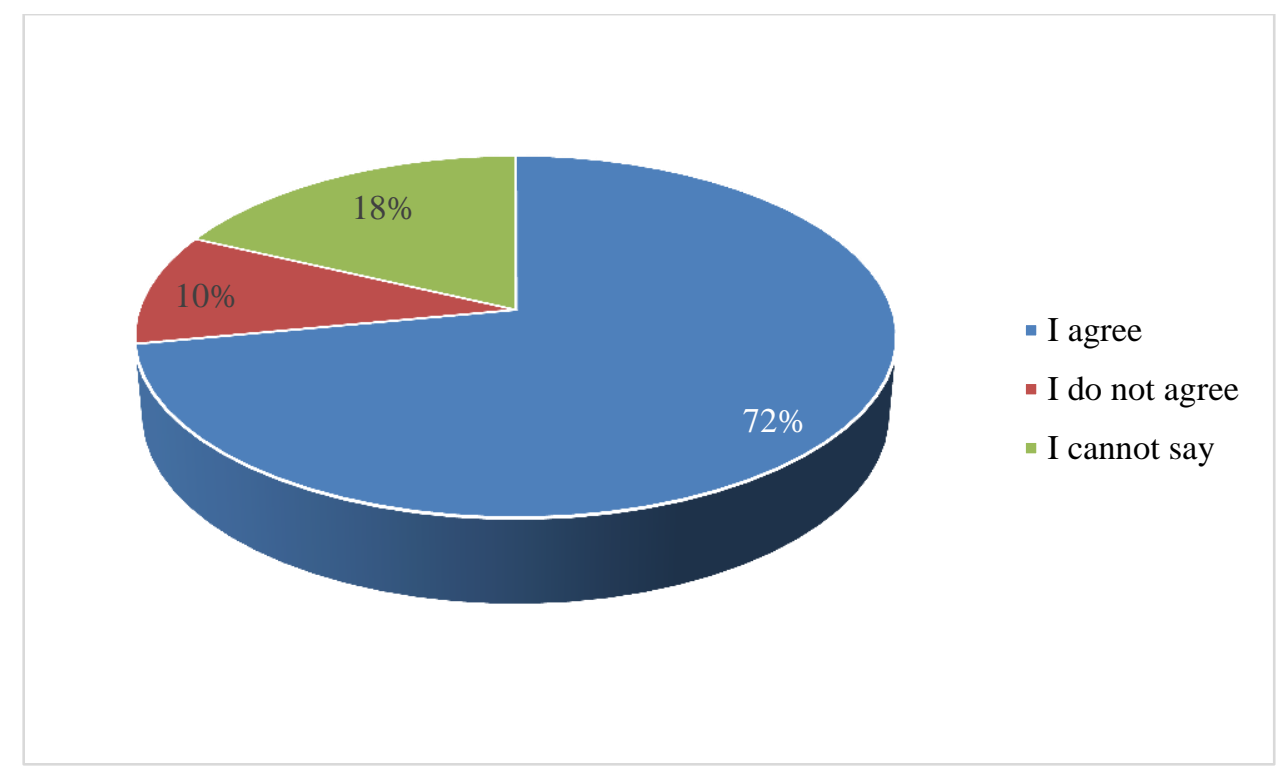

Figure 13. For respondents, social business becomes more relevant due to the growing civic participation in different contexts of society

One of the tasks was to assess the impact of social business in modern society.

It is important to properly measure the impact of social business on society as all its components must be useful. Social business is incapable of solving all the problems of modern society. According to the respondents, the reduction of social exclusion has the greatest impact on modern society $(82 \%)$. Increasing global and civic participation ensures participation of different social groups (74\%). Measures to reduce social exclusion ensure the integration of vulnerable members of society into the labour market and society (63\%). Social business influences modern society by developing their social and working skills (see Figure 14).)

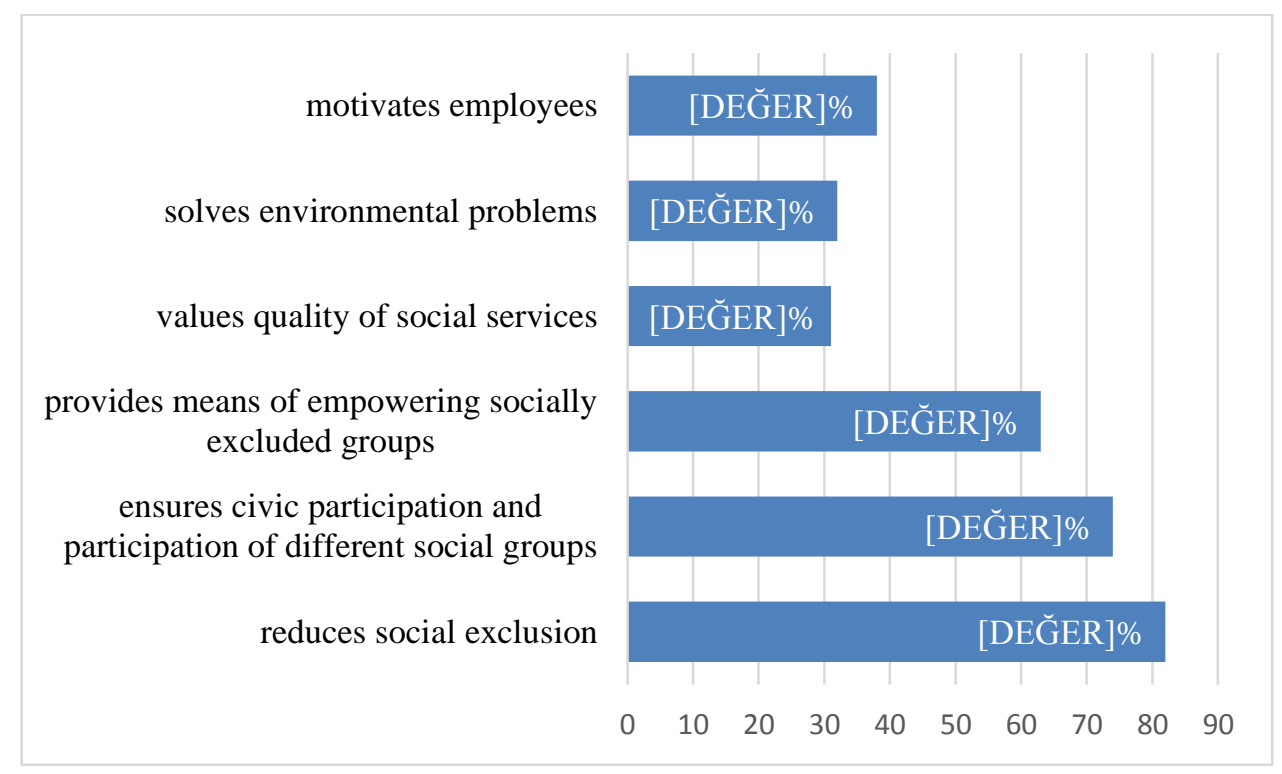

Figure 14. Distribution of respondents by impact of social business on modern society

The salad bar „Mano Guru“, operating in Lithuania is an example of social business. The company carries out economic activities - providing food service while being on a welfare mission - running a job reintegration program (employing addicts, dropouts). 


\section{Results, Conclusions and Recommendations}

\section{There were the results and conclusions acknowledged:}

1. Summarizing the concept of social business, it can be said to have distinctive features compared to traditional businesses - the goal is to measure social impact and benefit to society through job creation, social innovation, social cohesion to reduce social exclusion and inequality, as well as to help tackling environmental problems.

2. Respondents in the study identify social business by the fact that its' primary purpose is social mission, and that transparency and accountability are an integral part of social business. This shows that transparency has a positive impact on public confidence.

3. In analysing social business principles, respondents believe that the greatest benefit of social business is when profits go to solve a social problem or are reinvested in social business development.

4. Modern society is influenced not only by the development of social and work skills, but also by the general image and reputation of the company. The better the company meets the expectations and needs of a society, the stronger it is in a society.

5. In order to properly measure the impact of social business on society, it has been analysed which social business activities are the most useful. According to the respondents of the questionnaire survey, the reduction of social exclusion has the greatest impact on modern society.

6. Respondents believe that properly selected measures to reduce social exclusion ensure the integration of vulnerable members of a society into the labour market and society. One such measure is growing global and civic participation that ensures participation of different social groups in a society.

\section{The following recommendations and suggestions could be drawn:}

1. Transparency of social business is driven by positive examples that are shown, that is why companies must show the work they do and their impact on a society.

2. Social business not only opens up innovative opportunities to solve social problems but can also help reduce operating costs by investing in environmental protection, improving health of workers and a society, creating a market for green goods and services.

\section{Limitations of the study}

The study could have reached a wider spectre of respondents not only in the Southern part of Lithuania, but also in the whole country. Also, the number of respondents could have been expanded to search for more optional findings. Moreover, the social business representatives could have been used as the main factor of survey. Also, as it is an initial research, more research should be conducted in the future. To maintain the continuity of the survey, it is planned to assess consumer perceptions of the differences between social business and social responsibility in the future.

\section{References}

Čižikienė J., Urmanavičienė A. (2016). Adult Learning: Trends and Opportunities in the organization. Society. Integration. Education // Proceedings of the International Scientific Conference. Vol. 4.

European Commission. (2011). Social Business Initiative: Creating a favourable climate for social enterprises, key stakeholders in the social economy and innovation. Brussels.

Europen Commission. (2014). Socialinių įmonių ateičiai svarbus Europos lygmens renginys, 15 January 2014. <http://europa.eu/rapid/press-release_IP-14-20_lt.htm>

Gembickienė V., Leonienė B. (2015). Socialinis verslas - nauja galimybė stiprinti socialinę ekonomiką. Kauno kolegija.

Jakubavičius A., Leichteris E. ir Stumbrytė G. (2016). Socialinio verslo plètros Lietuvoje galimybių studija. Tyrimas atliktas Lietuvos inovacijų centro ir asociacijos „Žinių ekonomikos forumas“, [accessed $15 /$

10/2019]. <https://socmin.lrv.lt/uploads/socmin/documents/files/pdf/12778_soc_verslo_galimybiu_stud ija-20161209.pdf>

Kvieska V. (2015). Socialinio verslo ir verslumo kompetencijų sąsajos ISSN 1392-9569 E-ISSN 2351-6011 Socialinis ugdymas / Sumanioji edukacija.

Lietuvos Respublikos socialinio verslo koncepcija, patvirtinta Lietuvos Respublikos ūkio ministro 2015 m. balandžio 3 d. įsakymu Nr. 4-207. 3.

Lietuvos Respublikos socialinio verslo plètros ìstatymas [accessed 2019/09/9] <https://eseimas.lrs.lt/portal/legalAct/lt/TAP/92e1cf8064c411e8b7d2b2d2ca774092> 
Lietuvos statistikos departamentas <https://osp.stat.gov.lt/statistiniu-rodikliuanalize?indicator=S3R166\#/>

Melnikas B. (2017). Socialinis verslas: kūrimo ir plètros poreikiai. Viešasis administravimas, No 1-2 (5354), 64-81.

Navasaitienè S. (2017). Socialinio verslo iniciatyvos kaimo bendruomenèse. Tarptautinè mokslinèpraktinė konferencija Žemės ūkio gamintojų organizacijų ir kooperacijos plètros galimybės ir priemonès ES valstybèse.

Stroputė N., Kairytė M. (2016). Kurk Lietuvai. Kas daro socialinį verslą socialiniu verslu? Gerosios užsienio praktikos analizè. $\quad$ [accessed 2019/02/10].<http://kurklt.lt/wpcontent/uploads/2015/11/U\%C5\%BEsienio-\%C5\%A1ali\%C5\%B3-SV-vystymosi-irpl\%C4\%97tros-gerosios-praktikos-analiz\%C4\%97_Neringa-ir-Modesta>

Yunus, M., Moingeon, B. \& Lehmann-Ortega, L. (2010.) Building Social Business Models: Lessons from the Grameen Experience. Long Range Planning, 43, 309-325.13. 